\title{
Morphological changes in distant muscle fibers following thermal injury in Wistar rats $^{1}$
}

\author{
Alterações morfológicas das fibras musculares de um músculo distante da lesão térmica em \\ ratos Wistar
} \author{
Libertiv $^{\mathrm{V}}$ \\ ${ }^{\mathrm{I}} \mathrm{PhD}$, Associate Professor, Department of Biosciences, Federal University of Sao Paulo (UNIFESP), Brazil. \\ ${ }^{\text {II } M a s t e r ~ d e g r e e, ~ S c h o o l ~ o f ~ M e d i c i n e, ~ U S P, ~ S a o ~ P a u l o, ~ B r a z i l . ~}$ \\ ${ }^{\text {III }} \mathrm{PhD}$, Associate Professor, Department of Biosciences, State University of Sao Paulo (UNESP), Brazil. \\ ${ }^{\text {IV }} \mathrm{PhD}$, Associate Professor, Department of Anatomy, ICB-USP, Sao Paulo, Brazil. \\ ${ }^{v}$ Full Professor, Department of Anatomy, ICB-USP, Sao Paulo, Brazil.
}

Flavia de Oliveira ${ }^{\mathrm{I}}$, Luci Rezende Bevilacqua ${ }^{\mathrm{II}}$, Carlos Alberto Anaruma ${ }^{\mathrm{III}}$, Silvia de Campos Boldrini ${ }^{\mathrm{IV}}$, Edson Aparecido

\begin{abstract}
Purpose: Thermal injury causes catabolic processes as the body attempts to repair the damaged area. This study evaluated the effects of a scald injury on the morphology of muscle fibers belonging to a muscle distant from the lesion. Methods: Thirty Wistar rats were divided into control (C) and scalded (S) groups. Group S was scalded over $45 \%$ of the body surface, standardized by body weight. Rats in both groups were euthanized at four, seven and 14 days following the injury. The middle portions of the medial gastrocnemius muscles were sectioned, stained with hematoxylin and eosin and Picrosirius, and submitted to histological analysis. Results: Control group sections exhibited equidistantly distributed polygonal muscle fibers with peripheral nuclei, characteristic of normal muscle. The injured group sections did not consistently show these characteristics; many fibers in these sections exhibited a rounded contour, variable stain intensities, and greater interfiber distances. A substantially increased amount of connective tissue was also observed on the injured group sections. Conclusion: This experimental model found a morphological change in muscle distant from the site of thermal injury covering $45 \%$ of the body surface.
\end{abstract}

Key words: Morphology. Muscle Fibers, Skeletal. Connective Tissue. Burns. Rats.

\section{RESUMO}

Objetivo: A lesão térmica conduz o organismo a processos catabólicos a fim de reparar a área lesada. O propósito do presente estudo foi avaliar os efeitos da lesão térmica por escaldadura na morfologia das fibras musculares de um músculo distante da lesão. Métodos: Foram utilizados 30 ratos Wistar, divididos em: Grupo submetido à lesão térmica por escaldadura (S) e Grupo Controle (C). A escaldadura foi provocada em $45 \%$ da superfície corporal dos animais e padronizada pelo peso corpóreo. A eutanásia ocorreu nos períodos pós-lesão de quatro, sete e 14 dias. Retirou-se a parte média dos músculos gastrocnêmio medial os quais foram submetidos à técnica histológica de Hematoxilina-Eosina e Picrosírius. Resultados: O aspecto poligonal das fibras musculares, com núcleos periféricos, bem como a distribuição eqüidistante das mesmas, característico das descrições da musculatura normal, verificado nos animais do grupo C não foi uma constante nas fibras do músculo dos animais do grupo S. Nestes, muitas fibras exibiram contorno arredondado, diferentes intensidades de marcação bem como maior distanciamento entre as mesmas. Observou-se ainda aumento substancial da quantidade de tecido conjuntivo no grupo S. Conclusão: Houve alteração da morfologia do músculo distante da lesão como resposta à lesão térmica de $45 \%$ em modelo experimental.

Descritores: Morfologia. Fibras Musculares Esqueléticas. Tecido Conjuntivo. Queimaduras. Ratos.

${ }^{1}$ Research performed at Laboratory of Functional Anatomy Applied to Clinic and Surgery, Institute of Biomedical Sciences, University of Sao Paulo (USP), Brazil.

\section{Introduction}

In Brazil, $70 \%$ of burns occur in the home; $50 \%$ of the victims are children, and most of them are of low socioeconomic status ${ }^{1}$. Severe thermal injuries are typically followed by a catabolic state ${ }^{2-4}$. The catabolic response in skeletal muscle is the principle mechanism of protein loss in patients with thermal injuries, resulting in muscle weakness ${ }^{5-7}$ that delays recovery and contributes to disease. Muscle loss additionally exposes these patients to neuromuscular complications that increase hospital stay and mortality.

Some authors have reported that the systemic consequences of changes due to thermal injury, such as tissue destruction can be attributed to the increased metabolic rate 
that accompanies the body's attempts to repair the damaged regions $^{8,9}$.

Pereira et al. ${ }^{3}$ found that patients with lesions covering more than $40 \%$ of the body exhibited increased metabolism that persisted in most body tissues for at least one year after the trauma. The percentage of post-traumatic weight gain following injury indicated that thermal injury effectively promoted tissue loss due to systemic catabolism.

This study used hematoxylin and eosin (H\&E) and Picrosirius staining to clarify the morphological changes in muscle fibers and connective tissue belonging to the gastrocnemius muscle (GM), located away from the site of thermal injury.

\section{Methods}

\section{Animals and scald injury}

Thirty 21 day-old male Wistar rats (Rattus norvegicus) were individually housed in wire-bottomed metabolic cages for five days in a temperature-controlled room $\left(21-24^{\circ} \mathrm{C}\right)$ with a regular light-dark cycle. Water and food were available ad libitum. The use of metabolic cages facilitated the daily recording of daily body weights and cleaning of the cages to prevent contact with feces.

On the sixth day, 15 animals were anesthetized with an intraperitoneal (IP) injection of $40 \mathrm{mg} / \mathrm{kg}$ sodium pentobarbital (Hypnol 3\%, Fontoveter, Cristalia, Brazil), and the hair on the dorsal and ventral surfaces of the body was removed. A nonlethal scald injury was administered to 15 animals constituting the scalded group - (S) by immersing $45 \%$ of each rat's body -in $87^{\circ} \mathrm{C}$ water, as described by Walker and Mason ${ }^{10}$. Each animal had $30 \%$ of its dorsal and $15 \%$ of its ventral area exposed to scald injury for 10 and 3 seconds, respectively ${ }^{11}$. An additional 15 rats were untreated and comprised the control group (C). The rats in both groups were subcutaneously injected with the analgesic buprenorphine $(0.2 \mathrm{mg} / \mathrm{kg})$ immediately after sham or burn injury, and again $24 \mathrm{~h}$ later.

The animals were returned to their cages. The nutritional status of each rat was monitored by recording daily body weight and food intake. Four, seven and 14 days following the scald injury, five animals from each group were euthanized with a lethal IP injection of $100 \mathrm{mg} / \mathrm{kg}$ sodium pentobarbital. All procedures were approved by the Committee of Ethics in Animal Experimentation (CEEA - ICB/USP), protocol number 014/03.

\section{Histological analysis}

The GMs of euthanized rats from Groups S and C were examined. The medial part of each GM was dissected and transversely sectioned into proximal, middle and distal parts. The middle part was mounted in a cork block with Tissue Tek ${ }^{\circledR}$ embedding medium, frozen by immersion in liquid nitrogen-cooled isopentane, and stored at $-80^{\circ} \mathrm{C}$. Serial transverse sections $(10 \mu \mathrm{m}$ thick) were cut at $-25^{\circ} \mathrm{C}$ using a cryostat (CM 1850, Leica, Germany), and placed on coverlips.

The sections were stained with H\&E to allow a complete histological analysis that identified the morphological characteristics of the muscle fibers. Histological analysis of the collagen fibers was performed on sections stained with Picrosirius $^{12}$

Picrosirius photomicrographs were made under normal and polarized light to differentiate type I (red and yellow) and III (green) collagen. Photomicrographs made at different magnifications for the morphological analysis were evaluated by light microscopy with an attached camera (Axioscope 40, Axiocam HRc, Zeiss, Germany).

\section{Results}

The group $\mathrm{C}$ sections showed equidistantly distributed polygonal muscle fibers with intensely stained peripheral nuclei (Figure 1A). These characteristics correspond to descriptions of normal muscle, and were not consistently present in the Group $\mathrm{S}$ muscle fibers (Figure $1 \mathrm{~B}-\mathrm{C}$ and E-F). Many fibers in Group S sections exhibited rounded contours, variable stain intensities, weakly stained nuclei, and greater interfiber distances.
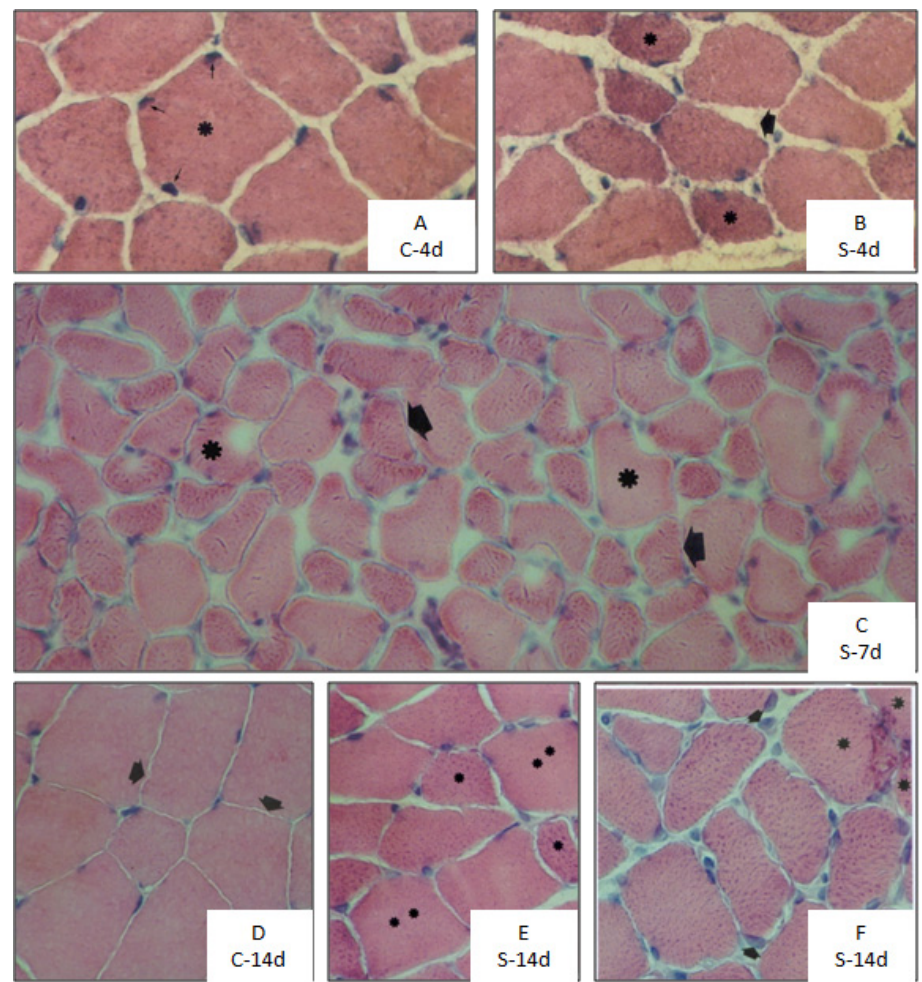

FIGURE 1 - Sections of rat gastrocnemius muscle stained with hematoxylin and eosin; panels show control group sections obtained at 4(A) and 14 (D) days, and scalded group sections obtained at 4(B), $7(\mathrm{C})$ and 14 (E and F) days after thermal injury. A. Normal fibers with polygonal aspects $(*)$, peripheral nuclei (arrows) and slightly irregular contours. B. Muscle fibers with irregular granules of acidophilus aspect $(*)$ and increased interfiber space (arrow). C. Disorganized muscle fibers of various shapes and sizes with irregular contours $\left(^{*}\right)$ and acidophilic granules (arrows). D. Muscle fibers of normal appearance, exhibiting some irregular contours (arrows) in certain areas of the muscle. E. Fibers containing acidophilic granules and splitting fibers $(*)$ interspersed with fibers of normal appearance $(* *)$. F. Muscle fibers with acidophilic granules, markedly irregular outlines, a large number of macrophage-like round cells (arrows) in the increased intercellular space. Note that some cells are undergoing degeneration (*). (Magnification: A-B and D-F, 715x; C, 275x.) 
The Group S sections also showed a substantial increase in the amount of connective tissue in the perimysia. This morphological alteration was more pronounced in sections obtained from rats euthanized 14 days after injury (Figure 2 A-B).

Analysis of the connective tissue under polarized light revealed the predominance of type I collagen. Collagen types did not differ between groups (Figure 2 C-D).

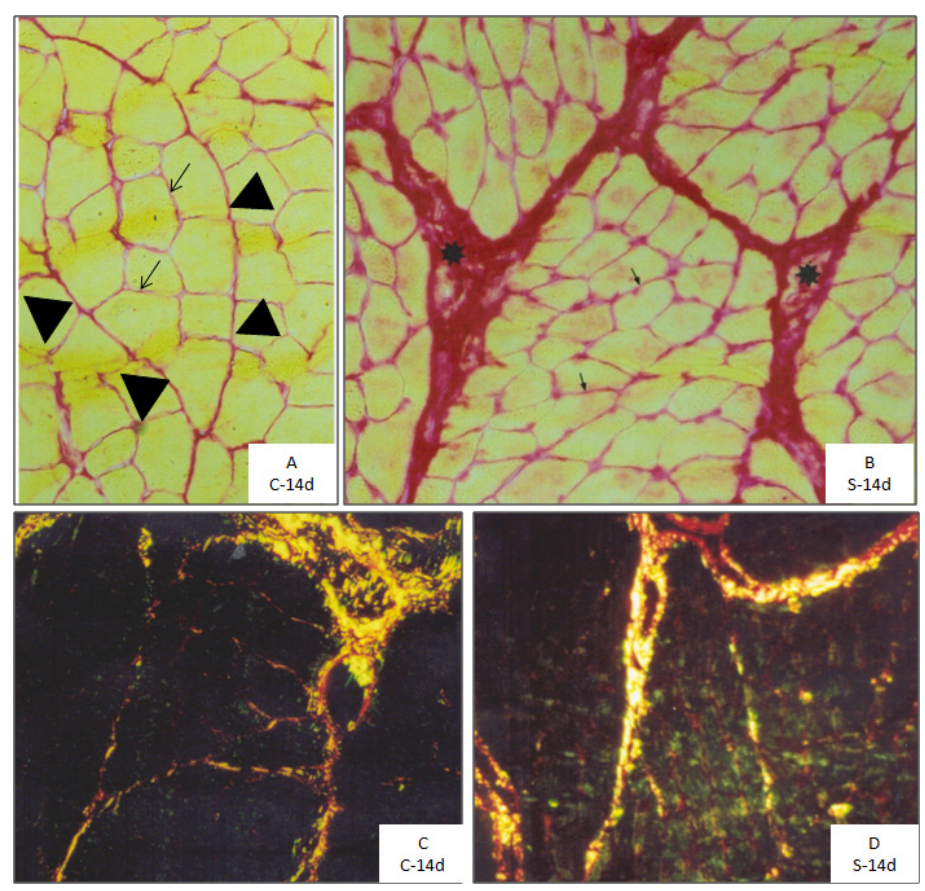

FIGURE 2 - Sections of rat gastrocnemius muscle stained with Picrosirius under normal (A-B) and polarized (C-D) light; panels show control (A and C) and scalded (B and D) group sections obtained 14 days after thermal injury. A. Stained perimysium (arrow heads) and endomysium (small arrows). B. Substantially increased amount of connective tissue $\left(^{*}\right)$ and preserved endomysium (arrows). C and D. Type I collagen characterized by red and yellow muscle wraps in both groups. (Magnification A-D, 275x.)

\section{Discussion}

Given the consequences of thermal injury to distant organs, the treatment of burn patients should not solely address the acute injury. It should also be concerned with the delayed rehabilitation of the patient due to the alterations of other tissues, such as skeletal muscle. Protein catabolism persists for months after thermal injury ${ }^{6}$ and can cause up to 2 years of growth retardation in injured children ${ }^{13}$.

This study found that morphological changes in muscle altered fiber form, but did not observe central nuclei that would indicate regeneration. However, muscle cell fusion was observed on the Group S micrographs taken 14 days after injury. This characteristic indicates the beginning of muscle regeneration process. A longer follow-up period would allow better monitoring of the morphological changes that accompany the regeneration of damaged muscle fibers after thermal injury.
A large number of nuclei were present in the intercellular space within 14 days after injury. Apoptosis causes the elimination of the nuclear core through the cell membrane; a smaller number of cores increases the cytoplasmic volume per nucleus, and the reduction in volume to restore balance in the cellular cytoplasm decreases the size of the cell (i.e., atrophy) ${ }^{14}$. Although the present study did not measure cell volume, the thickening of tissue in the intercellular spaces indicated that it decreased.

A recent study ${ }^{15}$ examined the morphology of the mandibular condyle of rats and the associations of thermal injury with pre and post-natal malnutrition. The researchers found changes in condylar type collagen after $45 \%$ of the animals's body surfaces were scalded, despite the distance of the mandible from the site of injury. The present study did not obtain similar results for skeletal muscle type I collagen fibers were predominat in both group. The only change observed in the Group S connective tissue was the filling of intercellular spaces caused by the apparent reduction in muscle fiber size, which was most pronounced 14 days after injury.

Another recent study ${ }^{7}$ analyzed the effects of a 12-week program of aerobic training combined with endurance exercise that was initiated seven weeks after thermal injury for children with lesions covering more than $40 \%$ of the body surface. The program was found to benefit these patients, as measured by clinical assessment of muscle loss. Future studies should use experimental models to investigate whether the morphological changes of cells distant from thermal damage are affected by exercise.

\section{Conclusion}

The present study found significant changes in rat muscle fibers after thermal injury by scalding in rats.

\section{References}

1. Piccolo NS. The 2002 Everett Idris Evans Memorial Lecture. Burn care in Brazil: ideas from the past, trends of the present, and hopes for the future. J Burn Care Rehabil. 2002;23(6):385-400.

2. Padfield KE, Astrakas LG, Zhang Q, Gopalan S, Dai G, Mindrinos MN, Tompkins RG, Rahme LG, Tzika AA. Burn injury causes mitochondrial dysfunction in skeletal muscle. Proc Natl Acad Sci USA. 2005;102(15):5368-73.

3. Pereira CT, Murphy KD, Herndon DN. Altering metabolism. J Burn Care Rehabil. 2005;26(3):194-9.

4. Atyeh BS, Gunn, SWA, Dibo SA. Metabolic implications of severe burn injuries and their management: a systematic review of the literature. World J Surg. 2008;32(8):1857-69.

5. Fang CH, Li BG, Fischer DR, Wang JJ, Runnels HA, Monaco JJ, Hasselgren PO. Burn injury upregulates the activity and gene expression of the $20 \mathrm{~S}$ proteasome in rat skeletal muscle. Clin Sci (Lond). 2000;99(3):181-7.

6. Hart DW, Wolf SE, Chinkes DL, Gore DC, Milcak RP, Beauford RB, Obeng MK, Lal S, Gold WF, Wolfe RR, Herndon DN. Determinants of skeletal muscle catabolism after severe burn. Ann Surg. 2000;232(4):455-65. 7. Al-Mousawi AM, Williams FN, Mlcak RP, Jeschke MG, Herndon DN, Suman OE. Effects of exercise training on resting energy expenditure and lean mass during pediatric burn rehabilitation. J Burn Care Res. 2010;31(3):400-8. 
8. Yu YM, Tompkins RG, Ryan CM, Young VR. The metabolic basis of the increase in energy expenditure in severely burned patients. JPEN J Parenter Enteral Nutr. 1999;23(3):160-8.

9. Wetzel JL, Giuffrida C, Schlancer A, Mcdowell-Montini C, Pietzyc C, Landry VL. Comparison of measures of physiologic stress during treadmill exercise in a patient with $20 \%$ lower extremity burn injuries and healthy matched and nonmatched individuals. J Burn Care Rehabil. 2000;21(4):359-66. 10. Walker HL, Mason ADJ. A standard animal burn. J Trauma. 1968;8(6)1049-51.

11. Newman JJ, Strome DR, Goodwin CW, Mason ADJ, Pruitt BAJ. Altered muscle metabolism in rats after thermal injury. Metabolism. 1982;31(2):1229-33.
12. Junqueira LCU, Bignolas G, Bretani RR. Picrosirius staining plus polarization microscopy, a specific method for collagen detection in tissue sections. Histochemistry. 1979;11(4):447-55.

13. Rutan RL, Herndon DN. Growth delay in postburn pediatric patients. Arch Surg. 1990;125(3):392-5.

14. Always SE, Siu PM. Nuclear apoptosis contributes to sarcopenia. Exerc Sport Sci Rev. 2008;36(2):51-7.

15. Oliveira BCC, Oliveira F, Martini DT, Prisco CRD, Riguetti MMS, Liberti EA, Boldrini SC. The relative effects of severe burn injury and pre- and post-natal protein deprivation on mandibular condyle morphology. Histol Histopathol. 2010;25(1):45-54.

Conflict of interest: none Financial source: FAPESP

\section{Correspondence:}

Flavia de Oliveira

Departamento de Biociências - UNIFESP

Av. Ana Costa, 95

11060-001 Santos - SP Brasil

flavia.oliveira@unifesp.br

Review: May 18, 2010

Accepted: June 21, 2010

\section{How to cite this article}

Oliveira F, Bevilacqua LR, Anaruma CA, Boldrini SC, Liberti EA. Morphological changes in distant muscle fibers following thermal injury in Wistar rats. Acta Cir Bras. [serial on the Internet] 2010 Nov-Dec;25(6). Available from URL: http://www.scielo.br/acb

\footnotetext{
*Color figures available from www.scielo.br/acb
} 